\title{
Pengaruh Model Discovery Learning Berbasis Permainan Train Smart (Kereta Pintar) Terhadap Kemampuan Literasi Membaca Tema 1 Subtema 2
}

\author{
Yudho Dewantoro*1, Asep Ardiyanto ${ }^{2}$, Arfilia Wijayanti ${ }^{3}$
}

${ }^{123}$ Jurusan Pendidikan Guru Sekolah Dasar, Universitas PGRI Semarang, Indonesia

\author{
A R T I C L E I N F O \\ Article history: \\ Received 18 August 2019 \\ Received in revised form \\ 19 September 2019 \\ Accepted 25 October 2019 \\ Available online 30 \\ November 2019 \\ Kata Kunci: \\ Model Discover Learning, \\ Permainan Train Smart \\ (kereta pintar), \\ Kemampuan Literasi \\ Membaca \\ Keywords: \\ Discover Learning Model, \\ Smart Train Game, Reading \\ Literacy Ability
}

\begin{abstract}
A B S T R A K
Tujuan yang hendak dicapai dalam penelitian ini adalah untuk mengetahui pengaruh model discovery learning dengan berbasis permainan train smart (kereta pintar) dapat meningkatkan kemampuan literasi membaca siswa kelas I SD Negeri 01 Galih. Jenis penelitian ini adalah penelitian kuantitatif dalam bentuk Pre-Experiment Desaign dengan desain One Group Pretest-Posttest . Populasi dalam penelitian ini seluruh siswa kelas I SD Negeri 01 Galih. Sampel yang diambil adalah 20 siswa kelas I dengan teknik Probability Sampling berbentuk sampling jenuh. Data dalam penelitian ini diperoleh melalui tes, dokumentasi, dan observasi. Hasil penelitian menunjukkan bahwa prosentase posttest $(75,30)$ lebih dari prosentase pretest $(62,05)$ serta berdasarkan hasil uji-t diketahui $t_{\text {hitung }}$ lebih dari $t_{\text {tabel }}(7,640>2,093)$ dan berdasarkan perhitungan uji regresi linier sederhana variabel bebas $X$ (aktivitas belajar) mempengaruhi variabel terikat $\mathrm{Y}$ (hasil belajar) sebesar $31,7 \%$. Dengan kata lain terdapat pengaruh positif pada model discovery learningberbasis permainan train smart (kereta pintar) terhadap kemampuan literasi membaca siswa kelas I SD Negeri 01 Galih. Berdasarkan hasil penelitian saran yang dapat disampaikan adalah supaya model discovery learning dengan berbasis permainan train smart (kereta pintar) dapat digunakan sebagai alternatif guru dalam mengajar pembelajaran di kelas.
\end{abstract}

\section{A B S T R A C T}

The aim to be achieved in this study is to determine the effect of discovery learning models based on the game train smart (smart train) can improve the literacy ability of reading students in grade I of SD Negeri 01 Galih. This type of research is quantitative research in the form of PreExperiment Desaign with One Group Pretest-Posttest design. The population in this study were all students in grade I of SD Negeri 01 Galih. Samples taken were 20 students in class I with a probability sampling technique in the form of saturated sampling. Data in this study were obtained through tests, documentation, and observation. The results showed that the percentage of posttest (75.30) was more than the percentage of pretest (62.05) and based on t-test results it was known that tcount was more than ttable $(7,640>2,093)$ and based on simple linear regression test calculations $X$ independent variables (learning activities) affect the dependent variable $Y$ (learning outcomes) by $31.7 \%$. In other words, there is a positive influence on the discovery learning model based on the game train smart (smart train) on the reading literacy ability of students in grade I of SD Negeri 01 Galih. Based on the research results, the suggestion that can be delivered is that the discovery learning model based on the smart train game can be used as an alternative teacher in teaching learning in the classroom.

\footnotetext{
${ }^{1}$ Corresponding author.

E-mail addresses: yudhodewan@gmail.com (Yudho Dewantoro)
} 


\section{Pendahuluan}

Pendidikan merupakan dasar dari seseorang untuk membentuk kepribadian yang lebih baik, melalui pendidikan setiap individu akan terbentuk kepribadianya seperti sikap perilaku moral dan empati yang lebih baik lagi, dengan kepribadian yang baik akan berpengaruh terhadap pembangunan suatu bangsa.

Dalam UU No. 20 Tahun 2003 tentang sistem pendidikan nasional pasal 1 yakni Pendidikan adalah usaha sadar dan terencana untuk mewujudkan suasana belajar dan proses pembelajaran agar peserta didik secara aktif mengembangkan potensi dirinya untuk memiliki kekuatan spiritual keagamaan, pengendalian diri, kepribadian, kecerdasan, akhlak mulia, serta keterampilan yang diperlukan dirinya, masyarakat, bangsa dan negara. Tujuan pendidikan juga untuk menciptakan sumber daya manusia yang berkualitas. Untuk mencapai tujuan pendidikan diperlukan bantuan dari masyarakat, upaya pemerintah dalam mewujudkan tercapainya tujuan pendidikan nasional yaitu diselenggarakanya pendidikan melalui tiga jalur sebagaimana yang tertuang dalam UU No. 20 Tahun 2003 pasal 13 ayat (1) yang berbunyi: "jalur pendidikan terdiri atas pendidikan formal, nonformal dan informal".

Salah satu jenjang pendidikan formal yaitu Sekolah Dasar (SD). Sekolah dasar merupakan salah satu sarana instansi memberikan layanan pendidikan yang diselenggarakan oleh pemerintah untuk menunjang pendidikan setiap warga negara agar memperoleh haknya dalam mengenyam pendidikan. Di antara banyak program pendidikan dari pemerintah, salah satu program yang diberlakukan di sekolah adalah Gerakan Literasi Sekolah (GLS). GLS merupakan kegiatan yang berkaitan dengan keterampilan membaca. Di mana keterampilan membaca berperan penting dalam kehidupan karena pengetahuan diperoleh melalui membaca. GLS adalah upaya menyeluruh yang melibatkan semua warga sekolah (guru, peserta didik, orangtua/wali murid) dan masyarakat sebagai bagian dari ekosistem pendidikan. Pembelajaran di sekolah seyogyanya diarahkan pada pembelajaran bersifat multilterasi yang mengcakup kegiatan :(a) literasi sebagai rangkaian kecakapan membaca, menulis, berbicara, kecakapan berhitung, dan kecakapan dalam mengakses dan menggunakan informasi; (b) literasi sebagai praktik sosial yang penerapannya dipengaruhi oleh konteks; (c) literasi sebagai proses pembelajaran dengan kegiatan membaca dan menulis sebagai medium untuk merenungkan, menyelidik, menanyakan, dan mengkritisi ilmu dan gagasan yang dipelajari, (d) literasi sebagai teks yang bervariasi menurut subjek, genre, dan tingkat kompleksitas bahasa." Kemendikbud:2018 dalam (Ananta Hardika Y:2018), Sedangkan menurut Abidin Yunus, (2017:279) Gerakan Literasi Sekolah adalah gerakan sosial dengan dukungan kolaboratif dari berbagi elemen dalam upaya untuk mewujudkan berupa pembiasaan membaca pada peserta didik yang dilakukan dengan kegiatan 15 menit membaca (guru membacakan buku dan warga sekolah membaca dalam hati, yang disesuaikan dengan konteks atau target sekolah.

Membaca merupakan salah satu langkah yang sangat menentukan berhasil atau tidaknya proses belajar mengajar yang diharapkan. Dengan membaca berarti menerjemahkan, menginterprestasikan tanda-tanda atau lambang-lambang dalam bahasa yang dipahami oleh pembaca. Menurut Dalman (2017:5) membaca merupakan suatu kegiatan atau proses kognitif yang berupaya untuk menemukan berbagai informasi yang terdapat dalam tulisan. Keterampilan membaca berperan penting dalam kehidupan karena pengetahuan diperoleh melalui membaca. Oleh karena itu, keterampilan ini harus dikuasai peserta didik dengan baik sejak dini untuk membiasakan budaya membaca. Menurut Darmono dalam (Faradina N:2017) minat baca adalah kecenderungan jiwa yang mendorong seseorang terhadap pembaca, minat baca ditunjukan dengan keinginan yang kuat untuk melakukan kegiatan membaca. Menurut Dalman (2017:8) di sekolah pembelajaran membaca perlu difokuskan pada aspek kemampuan memahami isi bacaan. Peserta didik dilatih secara intensif untuk memahami sebuah teks bacaan. Dalam hal ini peserta didik bukan menghafal isi bacaan tersebut melainkan memahami bacaan, Menurut Pratiwiningtyas (2017:1) literasi membaca merupakan proses memaknai hal-hal yang disampaikan oleh penulis, dan membawa pengalaman mereka sendiri pada teks yang dibacanya serta menciptakan sesuatu yang bermakna bagi kehidupan pembaca. Kemampuan literasi membaca setiap siswa dapat terukur melalui penilaian dengan menggunakan instrumen penilaian. Dalam penelitian ini peneliti memilih aspek kompetensi literasi membaca dengan acuan PISA (Programme for International Student Assessment). sebagai pijakan berpikir. Menurut Umamy (2012:6-7) Aspek kemampuan berpikir dalam soal literasi membaca PISA meliputikemampuan (1) membentuk pemahaman umum yang luas, (2) mengambil informasi, (3) mengembangkan interpretasi, (4) merefleksikan isi teks.

Peran guru sangat besar pegaruhnya terhadap kemampuan peserta didik dalam memahami isi bacaan. Guru bahasa indonesia sebaiknya mengajarkan peserta didik tentang strategi, metode, dan teknik membaca yang baik sehingga mampu memahami isi bacaan dengan baik pula. Kualitas pembelajaran dipengaruhi berbagai faktor diantaranya faktor dari peserta didik, guru, kurikulum/materi, media, metode, dan lingkungan. Guru mempunyai kewajiban mengembangkan semua potensi yang dimiliki 
peserta didik. Setiap peserta didik tentunya mempunyai karakteristik yang berbeda, mempunyai kelebihan dan kekurangan masing-masing tetapi sebagai guru yang profesional diharapkan dapat mengatasi masalah yang dihadapinya didalam kelas dengan melakukan inovasi-inovasi di dalam pembelajaran. Sehingga tujuan pembelajaran dapat tercapai dan pembelajaran menjadi aktif, interaktif, kreatif, efektif dan menyenangkan.

Berdasarkan observasi yang dilakukan di SDN 01 Galih terlihat bahwa guru kelas 1 dalam proses pembelajaran di kelas masih menggunakan pendekatan konvensional (ceramah) dan kurangnya inovasi dalam pembelajaran oleh guru. Guru aktif dalam menjelaskan materi pelajaran sementara peserta didik hanyalah sebagai pendengar saja. Peserta didik kurang diikutsertakan dalam pengelolaan informasi, sehingga peserta didik tidak aktif dalam mengikuti kegiatan pembelajaran. Kenyataan yang ada di lapangan mengungkapkan bahwa kemampuan membaca siswa kelas 1 SD Negeri 01 Galih masih rendah. Berdasarkan data yang diperoleh dari kelas 1 selama tiga tahun terakhir dapat diketahui bahwa sebagian besar hasil belajar pada mata pelajaran Bahasa Indonesia tergolong rendah, karena peserta didikyang memperoleh nilai diatas Kriteria Ketuntasan Minimum (KKM) dengan skor $\geq 75$ hanya sebanyak 21 peserta didik dari 54 atau sebanyak 39\%yang dapat mencapai daya serap materi pelajaran, sedangkan $61 \%$ atau sebanyak 33 peserta didik belum mencapai daya serap materi.

Mencermati adanya permasalahan di atas, perlu adanya inovasi dalam pembelajaran yang dapat menjadikan peserta didik lebih aktif dan beradadalam suasana belajar yang menyenangkan. Hal ini dilakukan agar peserta didikmampu mencapai tujuan pembelajaran yang diharapkan. Salah satu inovasi pembelajaran yang dapat digunakan untuk memperbaiki dan meningkatkanaktivitas belajar peserta didik menggunakan model discovery learning berbasis permainan kereta pintar. Wahyudin Darmawan (2018:111) menyatakan pembelajaran model discovery learning adalah teori belajar yang didefinisikan sebagai proses pembelajaran dimana siswa diberikan sebuah materi pembelajaran, kemudian diberikan acuan bagaimana materi tersebut dapat dijadikan sebuah jawaban atas pertanyaan atau masalah yang diberikan peserta didik. Model discovery learning ini mampu membantu peserta didik untuk mengembangkan, memperbanyak kesiapan, serta penguasaan keterampilan dalam proses kognitif.

Selain model pembelajaran discovery learning yang diterapkan peneliti juga ingin menggunakan permainan untuk membantu memudahkan peserta didik menangkap materi, permainan yang dimaksud yaitu permainan kereta pintar, permainan kereta pintar adalah permainan pembelajaran dengan menggunakankertas yang berukuran tebal dan berbentuk persegi yang ditulisiatau ditandai dengan unsur gambar dan abjad atau huruf tertentu. Kertas yang dimaksud menjadi kartu ini merupakan salah satu alat bantu pembelajaran yang termasuk dalam katagori Flash Card. Permainan pembelajaran ini mengandalkan kartu hurufyang menjadi faktor utama dalam proses pembelajaran. Kartu huruf dapatmembantu guru mencapai tujuan intruksional karena selain merupakanmedia juga dapat meningkatkankeaktifan peserta didik. Penelitian ini bertujuan untuk menjelaskan Pengaruh Model discover learning Berbasis Permainan Train Smart (Kereta Pintar) Terhadap Kemampuan Literasi Membaca Tema 1 Subtema 2 Siswa Kelas 1 Sd Negeri 01 Galih Tahun Ajaran 2019/2020.

\section{Metode}

Penelitian yang dilakukan peneliti merupakan penelitian kuantitatif dengan menggunakan metode one group pre-test post-test design yang menggunakan satu kelas kontrol yang di dalamnya terdapat pemberian perlakuan kepada subjek. Siswa nantinya akan diberikan perlakuan dalam proses pembelajaran untuk meningkatkan hasil belajar dan dilihat dari pengaruh hasil belajar siswa. Penelitian ini menggunakan Pre-test Posttest Design. Pada desain penelitian ini terdapat pretest sebelum diberikan perlakuan. Dengan demikian hasil perlakuan dapat diketahui lebih akurat, karena dapat membandingkan dengan keadaan sebelum dan sesudah diberi perlakuan. Dalam hal ini perlakuan digunakan untuk mencari perbedaan hasil belajar Bahasa Indonesia materi membaca Kelas I SD N 01 Galih Kecamatan Gemuh Kabupaten Kendal sebelum dan sesudah menggunakan model discovery learning berbasis permainan kereta pintar. Berdasarkan desain penelitian tersebut, terdapat satu kelas yang akan diberikan soal pada awal pembelajaran berupa pretest untuk mengukur hasil belajar siswa sebelum pemberian perlakuan. Setelah diberikan pretest selanjutnya siswa akan diberi perlakuan yaitu pembelajaran dengan menggunakan model pembelajaran discovery learning berbasis permainan kereta pintar. Pada akhir pembelajaran, siswa akan diberi soal posttest dan langkah selanjutnya membandingkan hasil belajar dari Pretest dan Posttest dalam pembelajaran tersebut.

Prosedur penelitian sesuai dengan desain tersebut adalah sebagai berikut: 


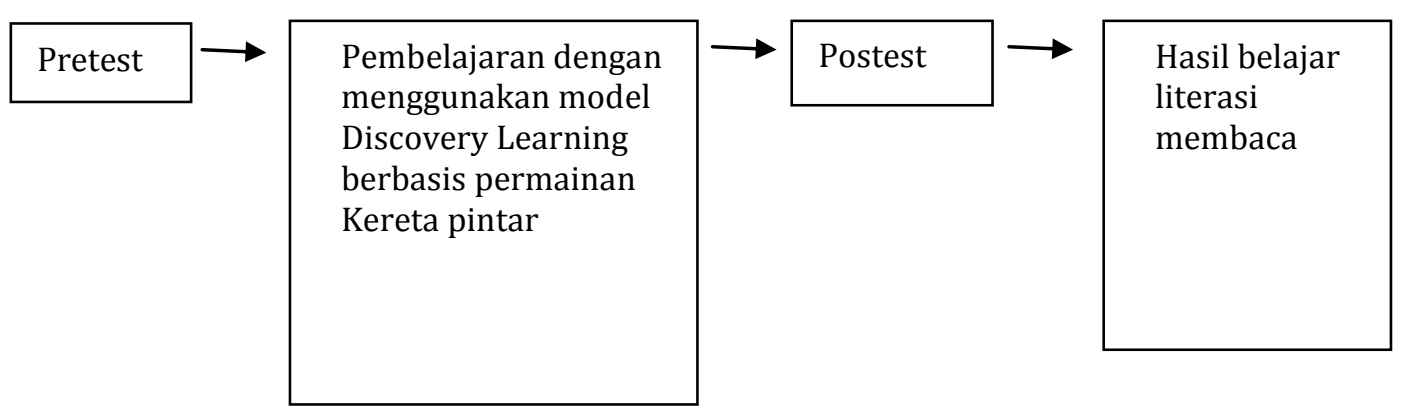

Gambar 1. Bagan Prosedur Penelitian

Berdasarkan bagan di atas dapat diuraikan dalam penelitian ini, peneliti terlebih dahulu membuat soal berdasarkan kisi-kisi. Peneliti selanjutnya melakukan uji coba soal pada kelas yang dipilih. Uji coba soal ini bertujuan untuk mengetahui validitas butir soal, tingkat kesukaran dan daya beda melalui analisis data. Peneliti memulai dengan melakukan pretest. Pretest ini bertujuan untuk menganalisa data awal. Setelah diberi perlakuan, peneliti menggunakan soal posttest. Pemberian soal posttest ini bertujuan untuk mengetahui hasil posttest yang nantinya akan digunakan untuk menyuksun hasil penelitian.

\section{Hasil dan Pembahasan}

Penelitian ini di laksanakan di SD Negeri 01 Galih Kendal. Dalam penelitian ini ada 2 variabel yaitu : (1) Variabel bebas (X) Model discovery learning berbasis permainan kereta pintar (train smart)dan (2) Variabel terikat (Y) Kemampuan literasi membaca tema 1 subtema 2 Siswa Kelas I SD Negeri 01 Galih Kendal. Penelitian ini merupakan penelitian kuantitatif dengan jenis One group pretest-posttest design. Data penelitian ini terdiri atas data pretest dan posttest pada tema 1 Diriku subtema 2 Tubuhku. Nilai hasil pretest sebagai pengukur kemampuan awal siswa dan nilai hasil posttest diambil dari hasil pengerjaan soal oleh siswa setelah dilakukan pembelajaran dengan Model discovery learning berbasis permainan kereta pintar (train smart).

Sampel penelitian ini diperoleh dari SD Negeri 01 Galih Kendal. Untuk menentukan instrumen penelitian maka perlu dilakukan uji coba instrumen utuk pretest dan posttest. Uji coba instrumen dalam penelitian ini berjumlah 30 butir soal. Setelah dilakukan uji coba instrumen, kemudian hasil uji coba instumen tersebut diuji dengan uji validitas, reliabilitas, tingkat kesukaran, dan daya pembeda. Dari hasil uji tersebut, didapatkan 15 soal yang valid, maka jumlah soal yang digunakan yaitu 15 butir soal.

Berdasarkan panjang kelas interval tersebut dapat digunakan utuk menentukan daftar distribusi frekuensi seperti pada tabel sebagai berikut:

Tabel 1. Distribusi Frekuensi Nilai Pretest

\begin{tabular}{ccc}
\hline Interval & Frekuensi & Persentase \\
\hline $33-45$ & 2 & $10 \%$ \\
$46-58$ & 5 & $25 \%$ \\
$59-71$ & 7 & $35 \%$ \\
$72-84$ & 4 & $20 \%$ \\
$85-97$ & 2 & $10 \%$ \\
Jumlah & 20 & $100 \%$ \\
\hline
\end{tabular}

Berdasarkan Tabel 1 dapat diketahui bahwa frekuensi hasil pretest yang memperoleh nilai 33-45 yaitu sebanyak 2 siswa atau 9\%, nilai 46-58 yaitu sebanyak 5 siswa atau 25\%, nilai 59-71 yaitu sebanyak 7 siswa atau 35\%, sedangkan nilai 72-84 yaitu sebanyak 4 siswa atau 20\%, dan yang mendapatkan nilai 85-97 yaitu sebanyak 2 siswa atau 10\%. Selanjutnya, distribusi frekuensi nilai pretest dapat disajikan dalam bentuk gambar sebagai berikut: 


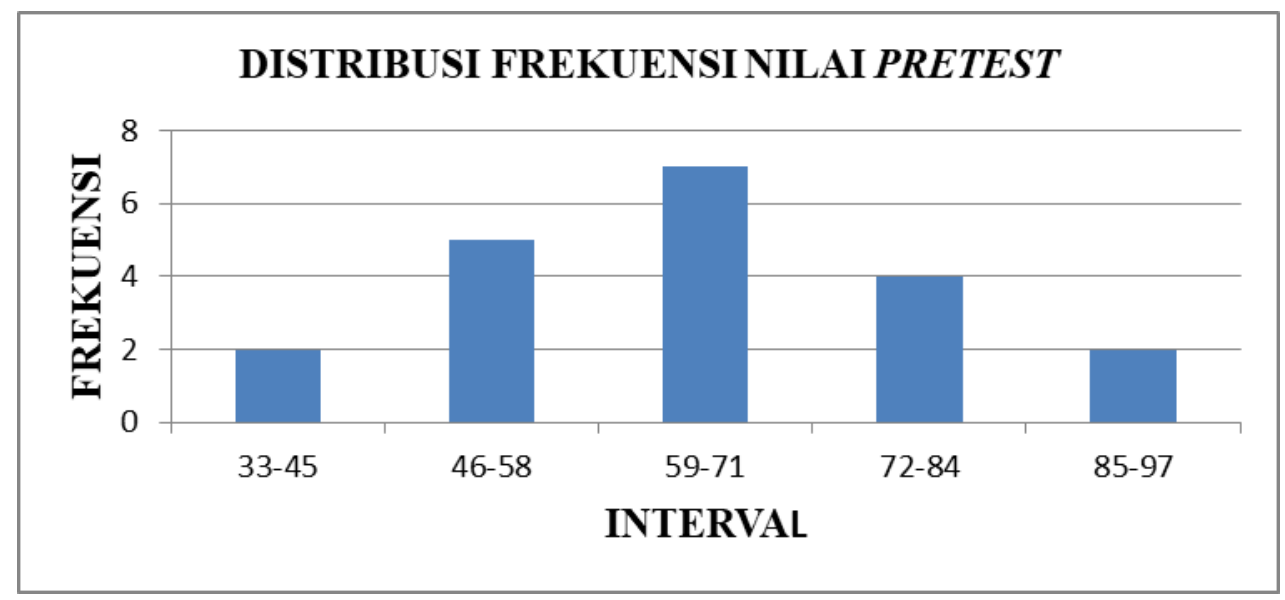

Gambar 2. Diagram Histogram Nilai Pretest

Data yang dgunakan dalam uji normalitas awal adalah data hasil pretest. Berdasarkan hasil perhitungan normalitas awal diperoleh data seperti pada tabel berikut.

Tabel 2. Normalitas Awal

\begin{tabular}{cccccc}
\hline Jenis & $\mathbf{N}$ & $\mathbf{L}_{\mathbf{0}}$ & $\mathbf{L}_{\text {tabel }}$ & Keterangan & Kesimpulan \\
\hline Pretest & 20 & 0,1017 & 0,190 & $\mathrm{~L}_{0}<\mathrm{L}_{\text {tabel }}$ & Berdistribusi normal \\
\hline
\end{tabular}

Berdasarkan data pretest yang dihitung menggunakan uji Liliefors diperoleh data $\mathrm{L}_{\text {tabel }}=0,19$ dan $\mathrm{L}_{0}$ $=0,1017$. Karena $\mathrm{L}_{0}<\mathrm{L}_{\text {tabel }}$ maka $\mathrm{H} 0$ diterima. Artinya, data nilai awal tersebut berasal dari populasi yang berdistribusi normal.

Setelah ditentukan nilai panjang kelas,maka dapat dijadikan sebagai pedoman untuk menentukan daftar distribusi frekuensi. Berikut adalah daftar frekuensi nilai posttest dapat dilihat pada tabel berikut ini:

Tabel 3. Distribusi Frekuensi Nilai Posttest

\begin{tabular}{ccc}
\hline Interval & Frekuensi & Persentase \\
\hline $47-57$ & 2 & $10 \%$ \\
$58-68$ & 5 & $25 \%$ \\
$69-79$ & 4 & $20 \%$ \\
$80-90$ & 5 & $25 \%$ \\
$91-100$ & 4 & $20 \%$ \\
Jumlah & 20 & $100 \%$ \\
\hline
\end{tabular}

Berdasarkan Tabel 3 dapat diketahui bahwa frekuensi hasil posttest siswa yang memperoleh nilai 47-57 sebanyak 2 siswa dengan persentase $10 \%$, nilai 58-68 sebanyak 5 dengan persentase $25 \%$, nilai 69-79 sebanyak 4 siswa dengan persentase $20 \%$, nilai 80-90 sebanyak 5 siswa dengan persentase $25 \%$, dan nilai 91-100 sebanyak 4 siswa dengan persentase $20 \%$. Selanjutnya data frekuensi nilai posttest siswa dapat disajikan dalam bentuk diagram histogram sebagai berikut: 


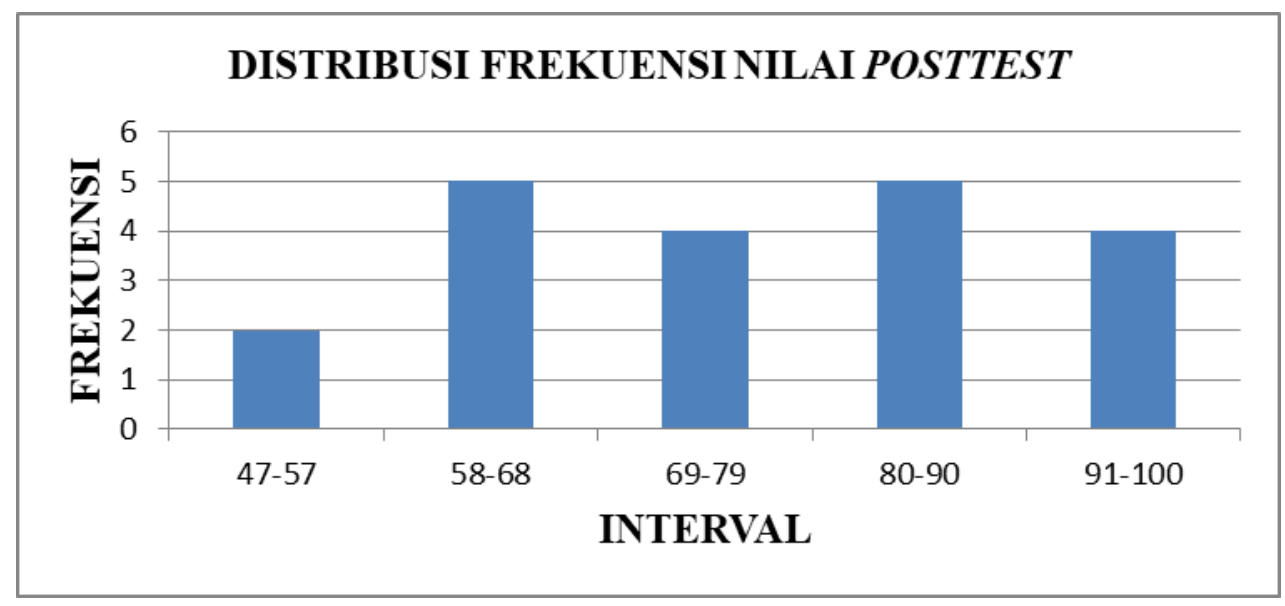

Gambar 3. Diagram Histogram Nilai Posttest

Data yang dgunakan dalam uji normalitas akhir adalah data hasil posttest. Berdasarkan hasil perhitungan normalitas akhir diperoleh data seperti pada tabel berikut:

Tabel 4. Normalitas Akhir

\begin{tabular}{cccccc}
\hline Jenis & $\mathbf{N}$ & $\mathbf{L}_{\mathbf{0}}$ & $\mathbf{L}_{\text {tabel }}$ & Keterangan & Kesimpulan \\
\hline Posttest & 20 & 0,1762 & 0,190 & $\mathrm{~L}_{0}<\mathrm{L}_{\text {tabel }}$ & Berdistribusi normal \\
\hline
\end{tabular}

Berdasarkan data hasil posttest diperoleh data yaitu $\mathrm{L}_{0}=0,1762$. Dengan banyaknya data $=20$, untuk taraf signifikansi 5\% maka dari tabel Liliefors diperoleh $\mathrm{L}_{\text {tabel }}=0,190$. Maka $\mathrm{L}_{0}<\mathrm{L}_{\text {tabel }}$ artinya, data nilai siswa tersebut berasal dari populasi yang berdistribusi normal.

Hipotesis yang digunakan adalah sebagai berikut:

$\mathrm{H}_{0} \quad$ : Jika $\mathrm{t}_{\text {hitung }} \leq \mathrm{t}_{\text {tabel }}$ maka, model discovery learning berbasis

permainan kereta pintar (train smart) tidak meningkatkan kemampuan literasi membaca peserta didik kelas 1 SDN 01 Galih.

$\mathrm{H}_{\mathrm{a}} \quad$ : Jika $\mathrm{t}_{\text {hitung }} \geq \mathrm{t}_{\text {tabel }}$ maka, model discovery learningberbasis

permainan kereta pintar (train smart) dapat meningkatkan kemampuan literasi membaca peserta didik kelas 1 SDN 01 Galih.

Berdasarkan hasil perhitungan uji-t antara nilai pretest dan nilai posttest maka diperoleh data sebagai berikut:

Tabel 5. Uji-t

\begin{tabular}{cccc}
\hline $\mathrm{T}_{\text {hitung }}$ & $\mathrm{T}_{\text {tabel }}$ & Keterangan & Kesimpulan \\
\hline 7,640 & 2,093 & $\mathrm{~T}_{\text {hitung }}>\mathrm{T}_{\text {tabel }}$ & $\mathrm{H}_{0}$ ditolak \\
\hline
\end{tabular}

Berdasarkan perhitungan di atas diperoleh $t_{\text {hitung }}=7,640$. Hal tersebut kemudian dikonsultasikan dengan $t_{\text {tabel }}$ dari tabel distribusi $t$ dengan $d b=N-1=20-1=19$, dan taraf signifikan 0,05 sebesar 2,093. Karena $t_{\text {hitung }}>t_{\text {table }}$ yaitu $7,640>2,093$, maka $\mathrm{H}_{0}$ ditolak dan $\mathrm{H}_{\mathrm{a}}$ diterima. Jadi terdapat perbedaan signifikannilai hasil pretest dan posttest. Sebelum dan setelah diberikan perlakuan pada peserta didik dapat meningkatkan hasil belajar kemampuan literasi membaca. Hal ini dibuktikan dengan nilai data awal dan nilai data akhir siswa meningkat dengan rata-rata pretest yaitu 62,05 sedangkan rata-rata posttest yaitu 75,30 . Dari data tersebut dapat disimpulkan bahwa data posttest meningkat signifikan dibandingan dengan data pretest.

Sehingga dapat dikatakan bahwa model discovery learning berbasis permainan kereta pintar (train smart) dapat meningkatkan kemampuan literasi membaca siswa kelas I SD Negeri 01 Galih. Dalam menentukan pengaruh model discovery learning berbasis permainan kereta pintar (train smart) terhadap kemampuan literasi membaca peserta didik, dalam penelitian ini menggunakan uji regresi linier sederhana dengan aktivitas belajar peserta didik sebagai variabel bebas (X) yang mempengaruhi variabel terikat ( $\mathrm{Y}$ ) yaitu hasil belajar. 


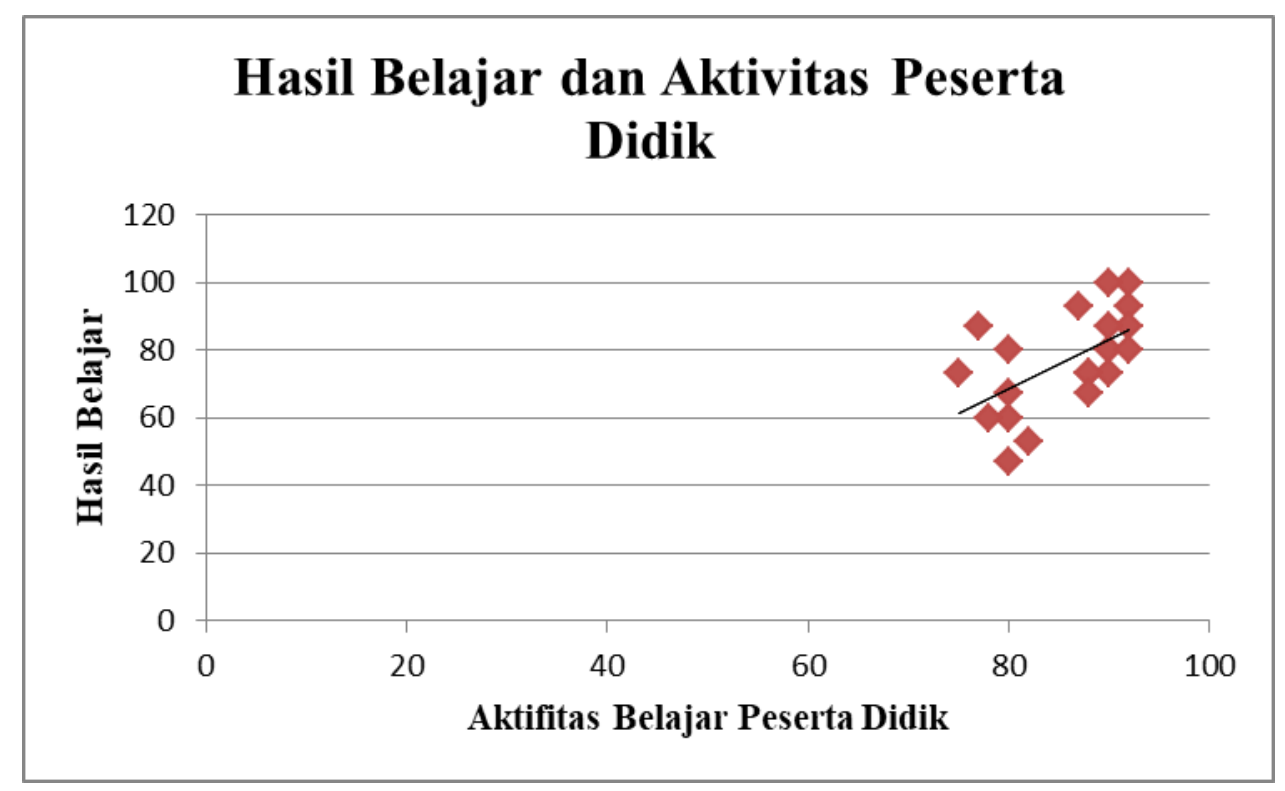

Gambar 4 Grafik Data Hasil Aktivitas Belajar Peserta Didik Dan Hasil Belajar

Berdasarkan perhitungan analisis statistik pada paparan di atas, maka di dalam pembahasan ini dijelaskan mengenai hasil dari analisis data. Tujuan penelitian ini adalah untuk mengetahui ada atau tidaknya pengaruh model discovery learning berbasis permainan kereta pintar (train smart) untuk meningkatkan kemampuan literasi membaca siswa kelas I SD Negeri 01 Galih.

Pada waktu dilakukan observasi di SD Negeri 01 Galih didapatkan masalah pada pembelajaran dikelas I yaitu peserta didik mengalami kesulitan dalam hal membaca, dalam pembelajaran dikelas I guru juga kurang menggunakan model dan media pembelajaran sehingga peserta didik kurang antusias dalam proses pembelajaran.

Untuk mengatasi masalah tersebut maka perlu dilakukan sebuah pembelajaran baru yang inovatif dan media pembelajaran yang mampu menarik perhatian peserta didik dalam pembelajaran. Peneliti mencoba memberikan solusi dengan memberikan perlakuan dengan menggunakan model pembelajaran discovery learningberbasis permainan kereta pintar.

Instrument penelitian yang dipilih dalam penelitian ini yaitu berupa tes yang berisikan 20 soal pilihan ganda. Hasil penelitian menunjukkan bahwa nilai keterampilan menulis peserta didik pada uji pretest didapatkan nilai terendah sebesar 33, nilai tertinggi sebesar 87 dan nilai rata-rata sebesar 62,05. Peserta didik yang tuntas diatas KKM 70 pada uji pretest sebanyak 6 peserta didik dan yang tidak tuntas sebanyak 14 peserta didik. Sedangkan pada uji posttest didaparkan nilai terendah sebesar 47, nilai tertinggi sebesar 100 dan nilai rata-rata sebesar 75,30. Pada hasil uji posttest menunjukkan bahwa peserta didik yang tuntas sebanyak 13 dan yang tidak tuntas sebanyak 7 peserta didik.

Untuk mengetahui normalitas sampel dari populasi, dalam penelitian ini menggunakan perhitungan uji liliefors. Pada taraf signifikan $5 \%$ dan $\mathrm{n}=20$. Uji normalitas dilakukan dengan data awal (pretest) dan data akhir (posttest). Uji normalitas data awal (pretest) untuk $\mathrm{n}=20$ dan taraf signifikan 5\% dengan metode lilieforsdiperoleh $\mathrm{L}_{\text {hitung }}=0,1017$ dan $\mathrm{L}_{\text {tabel }}=0,190$. Dari data tersebut dapat disimpulkan bahwa $\mathrm{L}_{\text {hitung }}<\mathrm{L}$ tabel. Sehingga $\mathrm{H}_{0}$ diterima. Jadi sampel berasal dari populasi yang berdistribusi normal. Uji normalitas data akhir (posttest) untuk $\mathrm{n}=20$ dan taraf signifikan $5 \%$ dengan metode liliefors diperoleh $\mathrm{L}_{\text {hitung }}=0,1762$ dan $\mathrm{L}_{\text {tabel }}=0,190$. Dari data tersebut dapat disimpulkan bahwa $\mathrm{L}_{\text {hitung }}<\mathrm{L}_{\text {tabel }}$. Sehingga $\mathrm{H}_{0}$ diterima. Jadi sampel berasal dari populasi yang berdistribusi normal.

Berdasarkan Uji t menyatakan bahwadalam perhitungan diperoleh $\mathrm{T}_{\text {hitung }}$ sebesar 7,640 sedangkan $\mathrm{T}_{\text {tabel }}$ dengan $\mathrm{db}=\mathrm{N}-1=20-1=19$, dan taraf signifikan 0,05 sebesar 1,725 . Karena $\mathrm{T}_{\text {hitung }}>\mathrm{T}_{\text {tabelyaitu }}$ $7,640>1,725$, maka $\mathrm{H}_{0}$ ditolak dan $\mathrm{H}_{\mathrm{a}}$ diterima. Artinya ada perbedaan signifikan hasil belajar sebelum dan sesusah menggunakan model discovery learning dengan berbasis permainan kereta pintar (train smart) Sehingga dapat dikatakan bahwa model discovery learning dengan berbasis permainan train smart (kereta pintar) dapat meningkatkan kemampuan literasi membaca siswa kelas I SD N 1 Galih.

Berdasarkan perhitungan koefisien determinasi dalam uji regresi linier sederhana, variabel $\mathrm{X}$ (aktivitas belajar) mempengaruhi variabel Y (hasil belajar) yaitu sebesar 31,7 \% . Dengan melihat data hasil penelitian tersebut maka dapat disimpulkan bahwa model Discovery Learning berbasis permainan 
kereta pintar berpengaruh signifikan terhadap hasil belajar peserta didik setelah diberikan perlakuan dikelas I SD Negeri 01 Galih Kendal.

Dalam Astuti (2015:15) menyatakan bahwa Kelebihan model discovery learning diantaranya: a) Membantu siswa untuk memperbaiki dan meningkatkan keterampilan-keterampilan dan proses-proses kognitif; b) Menimbulkan rasa senang pada siswa, karena tumbuhnya rasa menyelidiki dan berhasil; c) Menyebabkan siswa mengarahkan kegiatan belajarnya sendiri dengan melibatkan akalnya dan motivasi sendiri.

Teori-teori tersebut telah terbukti dengan hasil penelitian yang didapatkan selama penelitian berlangsung. Selain itu juga teori tersebutsejalan dengan kenyataan saat berada dilapangan. Pola interaksi peserta didik selama berlangsungnya kegiatan belajar mengajar pada saat penelitian sangat baik. Peserta didik sangat antusias dalam mengikut pembelajaran, peserta didik bersifat lebih aktif, reaktif dan munculnya rasa ingin tahu peserta didik yang tinggi.

Nasikhah (2016:82) menyatakan bahwa Game education adalah sebuah permainan yang digunakan dalam proses pembelajaran dan dalam permainan tersebut mengandung unsur mendidik atau nilai-nilai pendidikan. Teori tersebut terbukti sesuai dengan hasil penelitian yang didapatkan, permainan kereta pintar (train smart) dapat memicu minat belajar peserta didik, dan bermanfaaat bagi pendidik karena lebih inovatif dalam memberikan pelajaran yang diajarkan sehingga proses belajar mengajar menjadi menyenangkan dan efektif. Nugrahaeni, A (2017) menyatakan Penerapan model pembelajaran Discovery Learning dapat meningkatkan hasil belajar kimia kelas XI MIA 2 SMA Negeri 2 Singaraja Tahun Ajaran $2016 / 2017$.

\section{Simpulan dan Saran}

Berdasarkan hasil penelitian yang dilakukan di SD Negeri 01 Galih Kendal dapat disimpulkan bahwa terdapat pengaruh positif pada model discovery learningberbasis permainan kereta pintar (train smart) terhadap kemampuan literasi membaca siswa kelas I pada tema 1 Diriku subtema 2 Tubuhku. Hal ini dapat dilihat dari uji regresi linier sederhana dengan koefisien determinasi variabel X (aktivitas belajar) mempengaruhi variabel $\mathrm{Y}$ (hasil belajar sebesar 31,7\% dan rata-rata nilai posttest lebih tinggi dibandingkan dengan rata-rata nilai pretest. Diperkuat juga dengan hasil uji hipotesis dengan menggunakan uji-t yaitu diperoleh $t_{h i t u n g}=7,640$. Dari daftar distribusi $t$ dengan $d b=N-1=20-1=19$ dengan taraf signifikansi $5 \%$ diperoleh $t_{\text {tabel }}=1.725$. Karena $t_{\text {hitung }}>\mathrm{t}_{\text {tabel }}$ maka $\mathrm{H}_{0}$ ditolak maka $\mathrm{H}_{\mathrm{a}}$ diterima sehingga dapat disimpulkan bahwa nilai posttest peserta didik lebih baik dibandingkan dengan nilai pretest setelah diberikan perlakuan. Peserta didik mencapai peningkatan kemampuan literasi membaca pada model Discovery Leraning berbasis permainan kereta pintar (train smart) pada siswa kelas I SD Negeri 01 Galih Kendal. Hal ini terbukti dengan rata-rata nilai posttest mencapai 75,30. Sedangkan ratarata nilai pretest mencapai 62,05. Dapat disimpulkan bahwa model Discovery Learning berbasis permainan kereta pintar (train smart) berpengaruh terhadap kemampuan literasi membaca siswa kelas I di SD Negeri 01 Galih Kendal.

Berdasarkan hasil penelitian yang dilakukan, bahwa model discovery learningberbasis permainan kereta pintar (train smart) berpengaruh positif untuk meningkatkan kemampuan literasi membaca siswa kelas I SD Negeri 01 Galih Kendal sehingga saran yang bisa di paparkan yaitu: 1) Model pembelajaran discovery learningberbasis permainan kereta pintar (train smart) berpengaruh terhadap kemampuan literasi membaca siswa kelas I, sehingga dapat dijadikan sebagai alternatif model dalam pembelajaran, 2) Pembelajaran dengan model discovery learning ini dapat dikolaborasikan dengan permainan atau media yang lain sesuai dengan situasi dan kondisi di sekolah, dan 3) Pembelajaran dengan menggunakan model discovery learning berbasis permainan kereta pintar (train smart) dapat menumbuhkan kerjasama serta motivasi siswa untuk semangat belajar.

\section{Daftar Rujukan}

Abidin, Yunus. (2017). Pembelajaran Literasi. Jakarta: Bumi Aksara.

Ananta Hardika Y. (2018). "Gerakan Literasi Sekolah (Gls) Sebagai Optimalisasi Minat Baca https://library.upgris.ac.id/filedoc/fulltext/vqoya18438HARDIKA\%20YULINAR\%20ANANTA.pdfS iswa Sekolah DasarkecamantanWonosalam Kabupaten Demak" 29 Mei 2019 (19:59).

Astuti, M. S. (2015). Peningkatan keterampilan bertanya dan hasil belajar siswa kelas 2 SDN Slungkep 03 menggunakan model Discovery Learning. Scholaria: Jurnal Pendidikan Dan Kebudayaan, 5(1), 10 23. 
Dalman. (2017). Keterampilan Membaca. Jakarta: Rajawali Pers.

Faradina, N. (2017). Pengaruh Program Gerakan Literasi Sekolah terhadap Minat Baca Siswa di SD Islam Terpadu Muhammadiyah An-Najah Jatinom Klaten. Hanata Widya, 6(8), 60-69.

Kristin, F. (2016). Analisis model pembelajaran discovery learning dalam meningkatkan hasil belajar siswa SD. JURNAL PENDIDIKAN DASAR PERKHASA: Jurnal Penelitian Pendidikan Dasar, 2(1), 90-98.

Mawaddah, S., \& Maryanti, R. (2016). Kemampuan Pemahaman Konsep Matematis Siswa SMP dalam Pembelajaran Menggunakan Model Penemuan Terbimbing (Discovery Learning). EDU-MAT, 4(1).

Nasikhah, A. N., Widihastrini, F., \& Widodo, S. T. (2016). PENGEMBANGAN GAME EDUCATION PEMBELAJARAN PKn MATERI MENGHARGAI KEPUTUSAN BERSAMA KELAS V SD. Jurnal Kreatif: Jurnal Kependidikan Dasar, 7(1).

No, U. U. (20). tahun 2003 tentang sistem Pendidikan Nasional.

Nugrahaeni, A., Redhana, I. W., \& Kartawan, I. M. A. (2017). Penerapan Model Pembelajaran Discovery Learning Untuk Meningkatkan Kemampuan Berpikir Kritis Dan Hasil Belajar Kimia. Jurnal Pendidikan Kimia Indonesia, 1(1), 23-29.

Pratiwiningtyas, B. N., Susilaningsih, E., \& Sudana, I. M. (2017). Pengembangan Instrumen Penilaian Kognitif untuk Mengukur Literasi Membaca Bahasa Indonesia Berbasis Model Pirls pada Siswa Kelas IV SD. Journal of Educational Research and Evaluation, 6(1), 01-09.

Rohim, F., \& Susanto, H. (2012). Penerapan Model Discovery Terbimbing Pada Pembelajaran Fisika Untuk Meningkatkan Kemampuan Berpikir Kreatif. UPEJ Unnes Physics Education Journal, 1(1).

Umamy $^{1}$, E., \& Basuki, I. A. (2012). PENGEMBANGAN INSTRUMEN ASESMEN LITERASI MEMBACA DENGAN ACUAN PISA (PROGRAMME FOR INTERNATIONAL STUDENT ASSESSMENT).

Wahyudin Darmawan. (2018). Model Pembelajaran Di Sekolah. Bandung: PT Remaja Rosdakarya 